УДК 349.2

DOI https:/ / doi.org/10.32837 / yuv.v0i1.2081

\author{
О. Боєва, \\ кандидат юридичних наук, \\ суддя \\ Господарського суду Запорізької області
}

\title{
ОБМЕЖЕННЯ РОЗВИТКУ ІНСТИТУТУ СУДОВОГО ЗАХИСТУ ТРУДОВИХ ПРАВ В УКРАЇНІ У ПЕРІОД 1937-1945 рр. (ЧАСТИНА 2)
}

У першій частині цієї статті автором досліджені деякі аспекти стану судового захисту трудових прав з часів прийняття Конституції УРСР 1937 року та до початку Другої світової війни. Друга частина статті охоплює дослідження розвитку інституту судового захисту трудових прав за часів Другої світової війни.

22 червня 1941 р. фашистська Німеччина напала на Радянський Союз. На цьому етапі Другої світової війни громадяни всіх союзних республік СРСР стали на захист своїх земель, вели боротьбу проти загарбників як на військовому фронті, так i на трудовому, гартуючи перемогу над фашизмом. У перші ж дні війни мало місце посилення централізації управління. У відповідності до статті 49 Конституції СРСР 1936 року Указом Президії Верховної Ради СРСР від 22 червня 1941 р. було проголошено про введення воєнного стану. За змістом цього Указу фактично необмежені повноваження надавалися військовим радам фронтів, армій, військових округів, а там, де не було військових рад - вищому військовому командуванню військових з'єднань. На значній території СРСР (і на всій території УРСР) запроваджувався особливий правовий режим воєнного стану. Військове командування отримало право для потреб оборони застосовувати трудову, воєнно-квартирну, автогужову повинності, вилучати транспортні засоби, врегульову- вати час роботи установ, підприємств та організацій (встановлювати комендантську годину), забороняти в їд чи виїзд 3 населених пунктів, застосовувати в адміністративному порядку виселення, позбавлення волі на строк до 6 місяців, штраф до 3000 рублів. Накази, постанови і розпорядження відповідних військових інстанцій були обов'язковими для місцевих органів влади, державних та громадських організацій, усього населення місцевості. Винні у їх невиконанні притягалися до кримінальної відповідальності за законами воєнного часу [1;2].

На підставі Указу Президіï Верховної Ради СРСР від 26 червня 1941 року відпустки скасовувалися (замість відпусток мали виплачувати грошову компенсацію), вводилися обов'язкові надурочні роботи тривалістю від 1 до 3 годин на день (для осіб віком до 16 років - не більше 2 годин у день) [3]. Слід зазначити, що згодом (з квітня 1942 року) було скасовано виплату грошових компенсацій за відпустку до закінчення війни.

Проголошення воєнного стану та дуже складна бойова обстановка на фронті вимагали централізації державної влади та запровадження надзвичайних заходів, а тому у відповідності до ст. 49 Конституції СРСР 1936 року було створено неконституційний орган влади - Державний Комітет Оборони (далі по тексту ДКО). Згідно з Постановою Президії Верховної Ради СРСР, Ради Народ- 
них Комісарів СРСР та Центрального Комітету Всесоюзної комуністичної партії більшовиків від 30.06.1941р., указаному органу (ДКО) фактично надавалася необмежена влада, що неминуче тягло за собою обмеження компетенції республіканських і місцевих органів державної влади і державного управління [4].

Під час війни трудове законодавство союзних республік фактично не діяло, було повністю підкорене принципам і положенням законодавства СРСР, яке, своєю чергою, мало на меті не забезпечення та захист прав і гарантій працівників, а застосування таких методів і заходів в організації праці, які б у найкоротші строки сприяли налагодженню оборонної промисловості та випуску воєнної продукції в таких обсягах, щоб можна було здобути перемогу над німецько-фашистськими загарбниками.

Того часу працездатне населення України, евакуйоване зі своїми родинами далеко на схід від своїх домівок, працювало за новими правовими нормами не на теренах українських земель. Законодавча діяльність органів УРСР була фактично обмежена не тільки приписами союзних законодавчих актів воєнного часу, але й тим, що у період із серпня 1941 року до лютого 1943 року саме на території РСФСР здійснювали свою діяльність законодавчі та виконавчі органи влади української республіки (вони були евакуйовані до Саратова, а пізніше перебували в Уфі та Москві). У лютому 1943 р. центральні органи влади повернулися спочатку до Харкова, а потім до Києва. У березні 1944 р. Верховна Рада УРСР відновила свою діяльність. На визволеній території України відновлювалась діяльність і місцевих рад.

Найважливішими завданнями органів влади в ці важкі часи були організація захисту країни на фронтах, керівництво збройними силами, мобілізаційна робота 3 формування військових частин, забезпечення постачання армії, евакуація та перебудова промисловості на випуск військової продукції, масова трудова мобілізація, що викликало необхідність у додаткових нормативних документах, якими б передбачалися нові обмеження основних прав і свобод громадян, у тому числі у сфері захисту трудових прав. Такими нормативними актами були Указ Президії Верховної Ради СРСР від 26.12.1941 року та Указ Президії Верховної Ради СРСР від 13.02.1942 року [5; 6].

Як зазначав Ю. Гавриленко, у роки Великої Вітчизняної війни трудове право відійшло від своїх добровільно демократичних засад та об'єднало у собі елементи кримінального й адміністративного права, тобто трудовий договір було замінено адміністративним актом [7, с. 255].

Характерними ознаками законодавства часів війни стали масова трудова мобілізація, встановлення жорстких заходів примусу до праці (включаючи кримінальну відповідальність у вигляді ув'язнення) за порушення трудової дисципліни, за випуск неякісної продукції, за крадіжку і хуліганство на роботі. Такий відступ від основних засад і принципів трудового права був зумовлений тим, що суттєва частина працездатного населення (в основному чоловічої статі) поповнила лави збройних сил. Так, загальна кількість робочих та службовців у народному господарстві радянської держави скоротилася 3 31,8 млн осіб (у першій половині 1941 року) до 18 млн осіб (на початку 1942 року) [8, с. 23].

В умовах воєнного часу трудовою мобілізацією було охоплено майже все працездатне населення. 3 початку війни за Указом Президії Верховної Ради СРСР від 22 червня 1941 р. «Про воєнний стан» воєнній владі надавалося право застосовувати трудову повинність для виконання оборонних робіт [9].

Згодом для забезпечення кадрами підприємств та маючи на меті збільшення виробництва продукції на 
підприємствах воєнної промисловості Указом Президії Верховної Ради СРСР від 26 грудня 1941 р. усі працівники і службовці чоловічої і жіночої статі цих підприємств вважалися на період війни мобілізованими і закріплювалися для постійної роботи за тими підприємствами, на яких вони працювали [10].

Оскільки 3 кожним днем війни потреба у робочих руках тільки зростала, Указом Президії Верховної Ради СРСР від 13 лютого 1942 р. із метою забезпечення робочою силою підприємств і будівництв воєнної промисловості й інших галузей народного господарства, працюючих на потреби оборони, було визнано необхідним на період воєнного часу мобілізацію працездатного міського населення та встановлено, що мобілізації підлягає працездатне міське населення віком: чоловіки від 16 до 55 років та жінки від 16 до 45 років із числа тих, що не працювали в державних установах та підприємствах [11].

Також Постановою Ради Народних Комісарів СРСР від 10.08.1942 р. було регламентовано порядок проведення трудової повинності та визначено, що особи, винні у відмові або ухиленні від трудової повинності, а також у затримці осіб, працюючих на підприємствах і установах та залучених до трудової повинності, підлягають кримінальній відповідальності за законами воєнного часу [12].

Крім того, істотні зміни стосувалися таких інститутів трудового права, як робочий час і час відпочинку. Згідно з Указом Президії Верховної Ради СРСР від 26 червня 1941 р., директорам підприємств дозволялося встановлювати обов'язкові понаднормові роботи тривалістю до трьох годин на день. Чергові та додаткові відпустки було замінено грошовою компенсацією, яка відповідно до указів Президії Верховної Ради СРСР від 9 квітня 1942 р., 9 січня 1943 р. перераховувалась як заощадження на спеціальні рахунки працівників [13, с. 408-409].
Для подальшого забезпечення народного господарства кадрами (з урахуванням того, що мільйони солдат і офіцерів гинули або калічилися на фронті, а дорослих працівників не вистачало, оскільки їх продовжували призивати до лав арміi) із середини 1942 року до роботи на підприємствах оборонної промисловості стали в масовому порядку залучати дітей і підлітків віком від 12 до 16 років. До дітей і підлітків застосовувалися такі ж само жорсткі санкції (включаючи кримінальну відповідальність), як і до повнолітніх. Кримінальна відповідальність поширювалася за запізнення на роботу, за самовільне залишення робочого місця, за самовільний ухід 3 підприємства тощо. Неповнолітні працювали на заводах, виготовлюючи патрони, вибухівку, запасні частини до бойової техніки та інше приладдя для воєнної галузі. При цьому умови праці були жахливими. Діти і підлітки працювали на станках і верстатах, які за розміром призначалися для дорослих, а тому діти всю зміну мали вистояти на коробках або ящиках, які ставили впритул до обладнання, щоб вони могли дотягнутися до робочої поверхні. Фактично нехтувалися всі вимоги щодо безпеки праці. Здебільшого вони працювали у холодних цехах, на маючи теплого взуття та одягу, їжі, що давали на обід, було не досить. Крім відчуття голоду і втоми, неповнолітні працівники постійно хотіли спати, оскільки не можна було запізнюватися на роботу, транспорту не було, а тому доводилося вставати дуже рано і йти пішки до заводу. Діти і підлітки, як і дорослі працівники, під час війни не мали права на вихідні і на відпустку. Тобто, застосовуючи працю дітей і підлітків, держава не брала до уваги питання щодо дотримання трудових прав, а стосовно захисту їніх трудових прав у судовому або іншому альтернативному порядку взагалі не йшлося. 


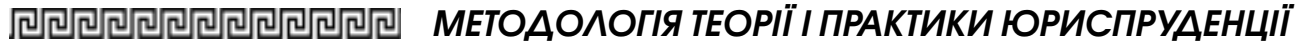

Висновки. Наприкінці 30-х років та на початку 40-х років XX століття у зв'язку з поширенням фашистських ідей і мілітаризацією гітлерівської Німеччини виникла загроза мирному існуванню радянських республік, а тому політика СРСР (зрозуміло, що й політика УРСР) змінюється у сфері регулювання трудових відносин не на користь демократичних засад. Вводиться державний примус до праці, більш жорсткими стають приписи законодавчих актів щодо робочого часу, звільнення за власним бажанням та стосовно самовільного уходу з підприємства або переходу з одного підприємства на інше.

Під час війни фашистської Німеччини проти Радянського Союзу на першому плані у державотворенні СРСР було намагання протистояти ворогові, здійснити відповідні оборонні заходи, укріпити збройні сили, евакуювати підприємства на схід від фронту, налагодити випуск воєнної продукції у великих розмірах.

Проголошення воєнного стану та дуже складна бойова обстановка на фронті вимагали централізації державної влади та запровадження надзвичайних заходів, а тому було створено неконституційний орган влади - Державний Комітет Оборони. Згідно з Постановою Президії Верховної Ради СРСР, Ради Народних Комісарів СРСР та Центрального Комітету Всесоюзної комуністичної партії більшовиків від 30.06.1941 р., указаному органу (ДКО) фактично надавалася необмежена влада, що неминуче тягло за собою обмеження компетенції республіканських і місцевих органів державної влади і державного управління. Того часу працездатне населення України, евакуйоване зі своїми родинами далеко на схід від своїх домівок, працювало за новими правовими нормами не на теренах українських земель. Законодавча діяльність органів УРСР була фактично обмежена не тільки приписами союзних законодавчих актів воєнного часу, але і тим, що у період з серпня 1941 року до лютого 1943 року саме на території РСФСР здійснювали свою діяльність законодавчі та виконавчі органи влади української республіки (вони були евакуйовані до Саратова, а пізніше перебували в Уфі та Москві).

Під час війни трудове законодавство союзних республік фактично не діяло, було повністю підкорене принципам і положенням законодавства СРСР, яке, своєю чергою, мало на меті не забезпечення та захист прав і гарантій працівників, а застосування таких методів і заходів в організації праці, які б у найкоротші строки сприяли налагодженню оборонної промисловості та випуску воєнної продукції в таких обсягах, щоб можна було отримати перемогу над німецько-фашистськими загарбниками.

3 перших днів війни дії державних органів були спрямовані на оборону і захист держави від ворога, що передбачало саме по собі перебудову державного механізму у відповідності до воєнного часу. Саме тому всі зміни у правовому полі СРСР (у тому числі у трудовому законодавстві) мали забезпечити втілення цих задач, а тому приймалися жорсткі правові рішення у галузі трудового права, незважаючи на необхідність дотримання трудових прав та виключаючи взагалі можливість їх захисту як у судовому, так і в альтернативному порядку.

Характерними ознаками трудового законодавства часів війни стали масова трудова мобілізація, встановлення жорстких заходів примусу до праці (включаючи кримінальну відповідальність у вигляді ув'язнення) за порушення трудової дисципліни, за випуск неякісної продукції, за крадіжку і хуліганство на роботі. Передбачені довоєнним Кодексом законів про працю гарантії щодо обмеження робочого часу, щодо обов'язковості надання вихідних і відпусток були зупинені до кінця війни. 
Застосовуючи працю дітей і підлітків, держава не брала до уваги питання щодо дотримання трудових прав, а стосовно захисту їніх трудових прав у судовому або іншому альтернативному порядку взагалі не йшлося.

В умовах воєнного стану сформувалося своєрідне нормативно-правове поле $з$ різними засобами стимулювання та примусу людей до військової i трудової діяльності. Характерною рисою його розвитку було посилення кримінальної репресії. Кримінальна відповідальність застосовувалася за діiі, які раніше каралися в адміністративному порядку (зокрема, пов'язані 3 необережністю, недбалістю, бездіяльністю) або регулювалися трудовим законодавством (наприклад, самовільне залишення роботи і т.ін.).

Справи стосовно порушників трудової дисципліни або щодо осіб, які порушували приписи вищевказаних Указів Президії Верховної Ради СРСР або Постанов Ради Народних Комісарів СРСР, розглядалися воєнними трибуналами без права на оскарження. Рішення у цих справах мали виконуватися негайно. За таких обставин можна стверджувати, що в Україні, яка на той час мала назву Українська Радянська Соціалістична Республіка (УРСР), як і в інших радянських республіках, у період 1937-1945 рр. мало місце значне порушення трудових прав працівників $з$ одночасним обмеженням інституту судового захисту трудових прав.

Наукова стаття присвячена розкриттю аспектів розвитку інституту судового захисту прав людини у сфері праці. Здійснено аналіз стану захисту трудових прав у Радянській Україні 3 періоду прийняття Конституиії УРСР 1937 року та за часів Другої світової війни.

Наприкінці 30-x років XX сторіччя Україна починає втрачати свою суверенність та незалеж- ність, що є закономірним наслідком здійсненої зміни конституційноправового статусу республіки. Це вбачається зі змісту конституційних положень різних років. Так, якщо взяти до уваги зміст доповнень до Конституиіi УСРР, прийнятих у 1925 роиі, то там було закріплено, що УСРР входить до складу СРСР як «незалежна республіка», згодом у Конституиіi УСРР 1929 року зазначалося, як «суверенна договірна держава», а про створення союзної держави мови не було. Проте в Конституиіï 1937 року (найменування УСРР було змінене на УРСР на Надзвичайному XIV з'їзді Рад у січні 1937 року) ці положення відсутні, $\epsilon$ лише запис про об'єднання республік у союзну державу. Конституція УРСР 1937 року замість з’їдів Рад, ЦВК УРСР ma їх Президій визначала найвищим органом державної влади республіки Верховну Раду УРСР. Верховна Рада УРСР вибирала Президію - колегіальний постійно діючий орган влади у періоди між сесіями Верховної Ради. В Україні поступово на перший план виходило керування загальносоюзних органів управління республіканськими об'єктами господарства, пріоритетною ставала дія загальносоюзного законодавства над республіканським як у вигляді копіювання змісту загальносоюзних законодавчих актів, так $i$ застосуванням союзних нормативних актів як актів прямої дії. Такі негативні тенденції не оминули $i$ галузь трудового права.

Теоретично прийняття у 1937 роияі Конституиіï УРСР мало б бути важливим кроком на иляху встановлення прогресивних принципів трудового права та закріплення нових підходів до удосконалювання захисту прав працівників, проте демократичні засади і положення Конституиіі залишилися декларативними. Конституцією проголо- 


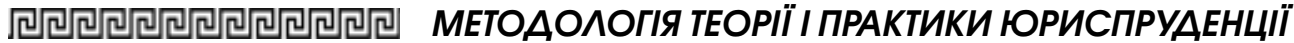

шувалося право кожного на працю (положення про загальну трудову повинність було відсутне), але проголошене Конституиією УРСР право на працю фактично було обов'язком працювати, а іншими нормативним актами відбувалося закріплення працівників за підприємствами, установами, заборонялося виїжжати на заробітки тошо.

Наприкінці 30-x - початку 40-x років минулого століття y всій союзній державі (y тому числі і в УРСР) з метою збільшення випуску продукції у всіх галузях народного господарства та підвищення продуктивності вводилися початкові засади примусової праці. Зокрема, особи, які не працювали без поважних причин (так звані «тунеядияі», «дармоїди», «нероби»), притягувалися до адміністративної або до кримінальної відповідальності; мало місце більш жорстке покарання за порушення трудової дисципліни, за виробництво продукиії з браком, за недотримання правил техніки безпеки.

У період Другої світової війни відбулося значне погіршення умов праці, падіння рівня прав та гарантій працівників, взагалі була відсутня можливість захисту їхніх трудових прав, тобто трудове право, покликане захищати права працівників, набуло певних регресивних ознак.

Такий відступ від основних засад і приниипів трудового права був зумовлений тим, що суттєва частина працездатного населення (в основному чоловічої статі) поповнила лави збройних сил. 3 метою забезпечення кадрами підприємств оборонного значення ma cільгосппідприємств (колгоспів, радгоспів) слід було змінювати політику держави у сфері регулювання праці, оскільки на теренах УССР, РСФСР та інших союзних республік діяли Кодекси законів про працю 1922-1924 років, за змістом яких передбачалися засади добровільної праці. Трудовим законодавством трудова повинність була передбачена лише у разі необхідності боротьби зі стихійними лихами та для виконання найважливіших державних завдань, mа лище на підставі конкретних постанов Ради Народних Комісарів. Такі демократичні засади не в змозі були забезпечити безперервну роботу оборонної промисловості, проведення оборонних $i$ будівельних робіт, заготівлю палива, безперебійного функиіонування транспорту тошо. Для забезпечення виконання иих завдань радянський уряд прийняв певну кількість указів Президіі Верховної Ради СРСР та постанов РНК СРСР, за якими вся держава переходила на воєнний стан $i$ фактично руйнувалися всі набуті раніше демократичні досягнення в сфері трудового права. Цей період характеризується мілітаризацією праці, мобілізацією працездатного населення, залученням до праці підлітків з 14 років, збільшенням тривалості робочого часу, скасуванням відпусток та введенням надурочних робіт.

Унікальність цього явища у плані дослідження тенези судового захисту трудових прав населення України полягає в тому, що такі регресивні тендениіі в основному мали місие не на території УРСР, а на території РСФСР, куди були евакуйовані українські підприємства разом зі своїми працівниками та їхніми родинами у зв'язку з тимчасовою окупацією німеиько-фашистськими військами території України. Також на території РСФСР у період із серпня 1941 року до лютого 1943 року здійснювали свою діяльність законодавчі та виконавчі органи влади української республіки (вони були евакуйовані до Саратова, а пізніше перебували в Уфі та Москві). 
Під час війни трудове законодавство союзних республік фактично не діяло, було повністю підкорене принципам $i$ положенням законодавства СРСР, яке, своєю чергою, мало на меті не забезпечення та захист прав і гарантій праиівників, а застосування таких методів $i$ заходів в організачї праці, які б у найкоротші строки сприяли налагодженню оборонної промисловості та випуску воєнної продукціі в таких обсягах, щоб можна було здобути перемогу над німецько-фаиистськими загарбниками.

Ключові слова: трудові права, інститут судового захисту трудових прав, трудове законодавство періоду Другої світової війни.

Boieva O. Development limitation of labour rights judicial defence institution in Ukraine between 1937 and 1945 (part 2)

The article covers development aspects of the institution of judicial defence of human rights at labour. The analysis of the labour rights defence condition in Soviet Ukraine from adopting the Constitution of the Ukrainian Soviet Socialist Republic of 1937 and throughout the Second World War is carried out.

In the late 30 s of the XX century Ukraine started losing its sovereignty and independence which was a natural consequence of the conducted change in republic constitutional and legal status. This follows from the content of constitutional regulations of various years. Thus, if amendments to the Constitution of the Ukrainian Socialist Soviet Republic adopted in 1925 are taken into account, it was enshrined that the Ukrainian Socialist Soviet Republic was the part of the Union of Soviet Socialist Republics as "an independent republic", thereafter, in the Constitution of the Ukrainian Soviet Socialist Republic of 1929 it was registered as "an independent contracting state", and there was no union state creation was mentioned. Nevertheless, in the Constitution of 1937 (the name of the Ukrainian Socialist Soviet Republic was changed to the Ukrainian Soviet Socialist Republic (UkrSSR) at the XIV Emergency Congress of Soviets in January 1937), these regulations are absent. There is only one record about joining the republics into one union state. Instead of the Congresses of Soviets, Central Election Commission of the UkrSSR and their Executive Committees, the Constitution of the UkrSSR of 1937 determined the Supreme Soviet of the UkrSSR as the republic highest body of state power. The Supreme Soviet of the USSR elected the Executive Committee - a collegial permanent power agency in the periods between the sessions of the Supreme Soviet. Incrementally, the governance of all-union governing bodies by republican economic facilities went to the foreground in Ukraine, the action of all-union laws above the republican laws was the priority - both in the form of copying the content of all-union legislative acts and adopting union regulatory acts as acts with direct effect. Such downward trends also concerned the field of labour law.

Theoretically, the adaptation of the Constitution of the UkrSSR of 1937 had to be an important step in the way of establishing progressive principles in labour law and consolidating the new approaches to improve the defence of workers' rights; however, the democratic principles and regulations of the Constitution remained declarative. The Constitution declared the right of everyone to work (the regulations on universal labour duty were absent), though the right to work declared by the Constitution of the UkrSSR was actually an obligation to work and, other regulatory acts assigned workers to the enterprises, institutions. It was forbidden to move in order to earn money for the living and so on. 


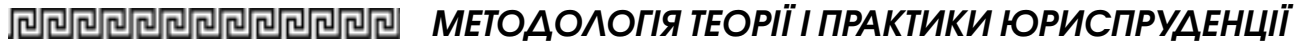

In the late $30 \mathrm{~s}$ - early 40 s of the previous century, the initial basis of forced labour was introduced in all union states (including, the UkrSSR) to increase production output in all fields of national economy and to improve productivity. Particularly, people who did not work without valid excuse (so-called "parasites", "freeloaders", "loafers") were brought to executive or criminal responsibilities. There was tougher penalty for violation of labour discipline, for producing items with defects, for non-observance of health and safety rules.

During the Second World War, there was a significant deterioration in labour conditions, a decline in workers' rights and guarantees. In general, there was no possibility to defend their labour rights, rather labour law referred to defend workers' rights gained certain regressive features.

Such deviation from the general foundations and principles of labour law was attributed to the fact that an essential part of the working population (mostly males) joined the armed forces. In order to provide the defence significance and farming enterprises (collective farms, state farms) with workforce, it was necessary to change the state policy in regulating the labour, since the Code of Labour Laws of 1922-1924, the content of which provided the foundations of voluntary work, acted on the territory of the USSR, the Russian Soviet Federative Socialist Republic (RSFSR) and other union republics. Labour laws foresaw labour duty only if it was necessary to combat natural disasters and to fulfil the most important state issues, but only on certain regulations of the People's Commissar Soviets. Such democratic principles were unable to ensure proper functioning of defence industry, the completion of defence and construction works, the fuel storage, the uninterrupted functioning of transport and so on. To ensure the fulfilment of the mentioned issues, the Soviet government adopted a certain number of Decrees of the Executive Committee of the Supreme Soviet of the USSR and Regulations of the People's Commissar Soviets of the USSR, according to which the entire state switched to the state of martial law and particularly destroyed all previously gained democratic achievements in labour law. This period is characterized by the labour militarisation, mobilization of the working population, the involvement of adolescents from the age of 14 into work, the increase in working hours, the annulment of holidays and the introduction of overtime work.

The uniqueness of this phenomenon in terms of research in the domain of judicial defence of population's labour rights in Ukraine lies in the fact that generally such regressive trends did not take place on the territory of the UkrSSR itself, but on the territory of the RSFSR where Ukrainian enterprises were evacuated together with their workers and families due to the temporary occupation of the Ukrainian territory by the Nazi army. Also, the legislative and executive power agencies of the Ukrainian Republic carried out their activities (they were evacuated to Saratov and later located in Ufa and Moscow) on the territory of the RSFSR during the period from August 1941 to February 1943.

During war, the labour laws of union republics actually did not function, it followed the law principles and regulations of the Union of Soviet Socialist Republics which, therefore, was intended not to ensure and defend the workers' rights and guarantees, but to introduce such methods and actions in work organization which in the shortest period could provide defence industry improvement and military production output in such capacities that it was possible to beat the Nazi invaders.

Key words: labour rights, institution of labour law judicial defence, labour law during the Second World War. 


\section{Література}

1. Конституция (Основной Закон) Союза Советских Социалистических Республик. Утверждена Чрезвычайным VIII съездом Советов Союза ССР 5 декабря 1936 года. URL: http:// wwr.hist.msu.ru/ER/Etext / cnst1936.htm (дата звернення: 05.08.2020).

2. Президиум Верховного Совета СССР. Указ от 22 июня 1941 года «O военном положении». URL: https: / / ru.wikisource.org/wiki/ (дата звернення: 04.08.2020).

3. Президиум Верховного Совета СССР. Указ от 26 июня 1941 года "O режиме рабочего времени рабочих и служащих в военное время». URL: https://ru.wikisource.org/wiki/ (Jama звернення: 05.08.2020).

4. Президиум Верховного Совета СССР, Совет народных комиссаров СССР, Центральньй Комитет ВКП(б). Постановление от 30 июня 1941 года "О создании государственного Комитета Оборонь». URL: https: / / ru.wikisource.org / wiki/ (дата звернення: 04.08.2020).

5. Президиум Верховного Совета СССР. Указ от 26 декабря 1941 года «Об ответственности рабочих и служащих предприятий военной промышленности за самовольный уход с предприятий». URL: http://wrw.economics. kiev.ua/download / ZakonySSSR / data04/tex16435.htm (дата зверненн:я 04.08.2020).

6. Президиум Верховного Совета СССР. Указ от 13 февраля 1942 г. «О мобилизации на период военного времени трудоспособного городского населения для работы на производстве и строительстве». URL: https: / / ru.wikisource.org / wiki/ (дата звернення: 04.08.2020).

7. Гавриленко Ю. Становлення українського трудового права: істо- ричнии аспект. Наукові праці МАУП. 2010. Bun. 2(25). C. 254-258.

8. Тонгузов В.А. Советское государство и право в период Великой Отечественной войны и послевоенные годы (1941-1964 ге.). Санкт-Петербург, 2008. URL: https://wwwelibrary.ru/ item.asp?id=19772766 (дата звернення: 20.07.2020).

9. Президиум Верховного Совета СССР. Указ от 22 июня 1941 года «O военном положении». URL: https: / / ru.wikisource.org/wiki/ (даma звернення: 04.08.2020).

10. Президиум Верховного Совета СССР. Указ от 26 декабря 1941 года «Об ответственности рабочих и служащих предприятий военной промышленности за самовольный уход с предприятий». URL: http://wrw.economics.kiev.ua/ download / ZakonySSSR / data04 / tex16435.htm (дата звернення: 04.08.2020)

11. Президиум Верховного Совета СССР. Указ от 13 февраля 1942 г. «О мобилизациии на период военного времени трудоспособного городского населения для работь на производстве и строительстве». URL: https: / / ru.wikisource.org / wiki / (dama звернення: 04.08.2020).

12. Совет Народных Комиссаров СССР. Постановление от 10.08.1942 № 1353 «O порядке привлечения граждан $к$ трудовой повинности в военное время». URL: http: / / www.consultant.ru / cons / cgi/ online.cgi? req $=$ doc\&base $=E S U \& n=26508 \#$ 02521609952408519 (дата звернення: 05.08.2020).

13. Бандурка О.М. Історія держави та права України : підручник для курсантів та студентів вищих навчальних закладів / О.М. Бандурка, М.Ю. Бурдін, О.М. Головко та ін. Харків : Майдан, 2018. 616 c. 